\title{
Unmet nursing needs of children in AICUs
}

Celine Gobréau-Kuijpers, RN, Intensive Care Nurse, Intensive Care Unit, Bronovo Hospital, The Hague, The Netherlands $(-)$

Jos Latour, RN MScN, Nurse Manager, Paediatric Intensive Care Unit, VU medical centre, Amsterdam, The Netherlands

Celine Gobréau-Kuijpers, Intensive Care Unit, Bronovo Hospital, P.O. Box 96900, 2509 JH The Hague, The Netherlands. email: p.gobreau@hccnet.nl

\section{INTRODUCTION}

There are not enough beds available within the nine specialist paediatric intensive care units (PICUs) in the Netherlands. This leads to the admission of children to adult intensive care units (AICUs). Because of this, the adult intensive care nurse is faced with the fact that he or she may have to provide care for young patients. In the opinion of the authors, it is often not safe to admit children to the AICU, because nurses and doctors lack the appropriate knowledge, skill and expertise to care for them. Unfortunately, the bed situation in the Netherlands for children needing intensive care is not likely to change in the foreseeable future. Thus, in the interim, it would be much better to set standards, which should be met in the AICU, to meet the needs of children (Paladichuk, 1998). This article outlines the training, experience and preconditions necessary to provide children in an AICU with safe, high-quality, nursing care.

The inadequate provision of PICU has been regularly brought to the attention of the public in the Netherlands, and it is a very real possibility that a child requiring critical care nursing will be cared for by AICU nurses. In the Netherlands, there are almost 80 recognised PICU beds, but due to lack of staff only 60-65 beds are currently being used. About 300 children, out of an annual admission rate of 3,500-4,000, are refused every year by PICUs due to a lack of available beds. These 300 children are mostly being admitted to an AICU, despite the fact that there is a medical indication for PICU (Köhler, 1998).

\section{BETTER CARE WITH PICU}

In comparison with AICU, the nine Dutch PICUs, present in the eight university hospitals, have proven to be of major importance for the specialised treatment of critically ill children (Gemke et al., 1995; Pearson et al., 1997). The PICU, which is also the tertiary centre for paediatrics, is a separate department for children, with equipment specialised for children, nurses trained to care for critically ill children, paediatric intensive care doctors, and the hospital's surgeons and medical specialists expert in the treatment of children. Various studies have shown that the mortality rate is greater in children admitted to a general hospital ICU instead of a PICU (e.g. Gemke, 1997; Pollack et al.,
1991). The number of children treated in secondary centres (i.e. general hospitals that treat children) is not exactly known.

In general, there are two main causes for the different mortality rates between secondary and tertiary centres: average severity of the illness and quality of care. Two multicentre studies in the Netherlands and the USA have shown, by means of a clinical scoring system, that most critically ill children have a better chance of survival if they are admitted to a PICU instead of a general ICU (Gemke, 1996). Furthermore, a Dutch and an Australian study have shown, that in about $75 \%$ of cases, the state of health of children returned to their pre-admission level, within a year of discharge from a PICU (Gemke et al., 1995; Pollack et al., 1991; Gemke, 1996). Figures for the mortality in PICU are considerably favourable when compared with those for children cared for in an AICU.

\section{PAEDIATRIC ADMISSIONS TO ICU}

The admission of a critically ill child frequently takes place in an emergency and accident department of a general hospital. Every general hospital must therefore be able to carry out the stabilisation of a child before transportation to a PICU. At present, neonatal intensive care is governed by Article 2 of the Dutch Special Medical Services Act $(1983,1997)$. This statutory regulation means that the tertiary hospital is responsible for the admission of neonates to a neonatal intensive care unit, and can be held responsible for doing so by the referring general (secondary) hospital.

However, the situation is different for children (i.e. those older than a neonate) in a general hospital. In the case of a child in a general hospital, requiring intensive care, it is the responsibility of the paediatric doctor from the general hospital to find a PICU bed rather than that of a tertiary centre to provide one. If no bed is available in the nearest tertiary hospital, the doctor may try to find a bed in another tertiary centre for a child not treatable within his own hospital. However, if he is not successful, the general hospital must treat the child, even if they are not well equipped for the task, i.e. even if the AICU nurses are not adequately prepared to care for the child, due to their lack of specialist education and experience. 


\section{DIFFERENCES BETWEEN CHILDREN AND ADULTS}

As children grow, the differences between children and adults become less, but this is not simply a matter of size. In particular, the child is an individual, and develops at his own speed, both mentally and physically, into adulthood (Sanders-Woutstra, 1988). Each age has its own physiology, pathology, pathophysiology and psychology, which determine the way the child in the ICU should be approached. Because of this, the same problem can present itself in a different manner in different children.

Despite the fact that a child in the ICU is often very ill, or treated so intensively that establishing normal contact is difficult or even impossible, medical and nursing staff need to be well informed about the mental and social functioning of the child at different ages. All staff members, permanently or temporarily working in the ICU, need to provide the best possible care to the child and its parents in close co-operation. The emotional vulnerability of children, and the stage of their intellectual development, require specific approaches to limit or prevent harmful consequences, not just in the short term but also in the long term.

Nursing risks are significantly higher with children because unjustifiable, omitted or incorrect actions are more likely have harmful consequences, which are also usually more serious than in adults (van der Brink et al., 1995). The normal values of respiratory frequency, heart rate and blood pressure in children depend on their age (see Table 1). It is important that a nurse knows these differences in normal values, so that they are interpreted correctly and appropriately applied to interventional therapy.

To illustrate this, we will describe some of the major (patho)physiological differences between children and adults.

\section{RESPIRATION}

One example of an important difference between adults and children is the relatively large tongue in small children, which increases the risk of obstruction of the respiratory tract and complicates visualisation during endotracheal intubation.

The possibility of a respiratory infection in children is also greater because the trachea, being shorter in children, is closer to the bronchi compared with an adult. Oxygen supply in children is very important since the child's metabolism, and thus its oxygen consumption in relation to body weight, is much higher than in adults. The risk of exhaustion in children due to increased breathing is increased because the thoracic wall is more compliant and will retract, and the diaphragm has weaker muscle movement (Hewitt-Taylor, 1999). The nurse must therefore pay special attention to a child's respiration, particularly when respiratory problems do exist.

\section{NEUROLOGY}

The central nervous system in a newborn is not mature (HewittTaylor, 1999). Only from the age of six years will a child meet

\begin{tabular}{|c|c|c|c|}
\hline Age & Heart rate & Blood pressure & Respiratoy rate \\
\hline 1 month & $100-180$ & $85 / 50$ & $30-80$ \\
\hline 6 months & $100-160$ & $90 / 53$ & $30-60$ \\
\hline 1 year & $90-140$ & $91 / 54$ & $20-40$ \\
\hline 2 years & $80-140$ & $91 / 56$ & $20-30$ \\
\hline 6 years & $75-100$ & $96 / 57$ & $20-25$ \\
\hline 10 years & $60-90$ & $102 / 62$ & $17-22$ \\
\hline 12 years & $55-90$ & $107 / 64$ & $17-22$ \\
\hline 16 years & $50-90$ & $117 / 67$ & $15-20$ \\
\hline
\end{tabular}

the maximum neurological score of the Glasgow Coma Scale used in adults. In order to make possible a correct assessment of the neurological state, several Paediatric Glasgow Coma Scales (see Table 2) for young children (less than six years of age) have been developed (Teasdale and Jennett, 1974).

\section{BODY COMPOSITION}

Children also differ from adults with regard to body composition, in the relationship between fat tissue and muscle tissue, and in body fluids. This means that the dose of medications cannot always be easily calculated. The route of elimination and the time needed to eliminate a drug from the body also differ in children, because the kidneys and liver, among other things, are not fully functional. Children can show a specific sensitivity to drugs.

Compliance with therapy and the administration of drugs can also cause problems. The nurse must therefore be acquainted with the doses of the medication to be administered to the child and how best to manage drug administration (van der Brink et al., 1995).

\section{CARE STANDARDS FOR CHILDREN IN AN AICU}

The general hospital should meet some baseline standards to enable them to provide care for critically ill children in a responsible way. The emergency department should be able to provide critical care and stabilisation of critically ill children at all times. Relevant training should be given within the accident and emergency course and qualified nurses must always be available.

In the Netherlands, first aid to children is only now being standardised. However, in England, an advanced paediatric life support course is available. Nurses who have undertaken this course appear to have the necessary skills to take care of children in an emergency (Duval, 1997; Latour, 1998a; Latour, 1998b; Turner, 1997; Turner, 1998; Latour, 2000). For nurses in the Netherlands, the educational option is to follow the Paediatric Advanced Life Support (PALS) course (www.sshk.nl).

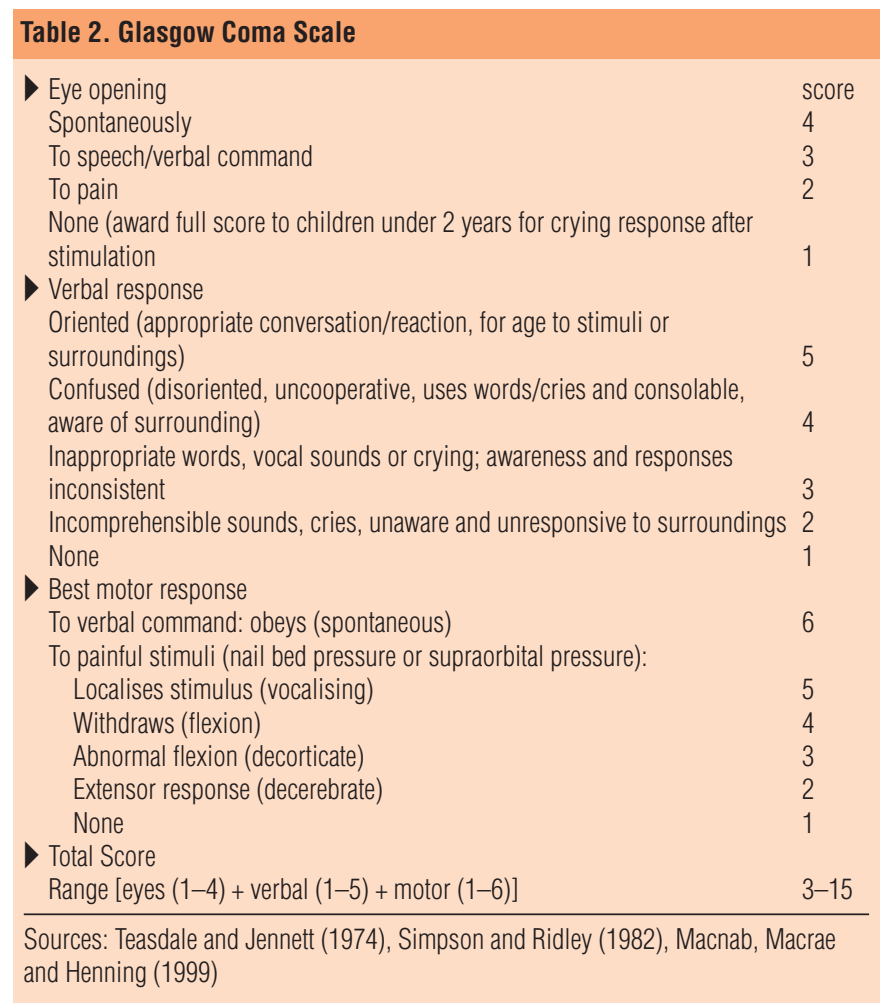




\section{Emergency surgery}

Elective surgery, involving a high degree of risk to the child, should take place in a tertiary hospital but it must also be possible to perform emergency surgery in a secondary centre. After stabilisation in an AICU, the child, if possible, should be transferred to a PICU. In co-operation with the anaesthetist and a paediatrician, stabilisation and 24-hour monitoring of children must be possible in an AICU, until transfer to a PICU is possible.

\section{Older children}

A general ICU must be able to take care of children that physically can be nursed and treated as an adult. This is possible from about the age of 15 years old, when a PICU is full, or when it concerns a short-term (i.e. for less than 24 hours) ICU admission. However, it should be borne in mind that these children are still maturing mentally and will need psychological support, so a paediatrician needs to be available.

\section{Types of expertise needed}

On the basis of differences in anatomy, physiology and psychology between children and adults, various problems arise in terms of respiration, circulation, fluid and electrolyte balances, metabolism, thermoregulation and function of the central nervous system (van der Brink et al., 1995; Paladichuk, 1998; Hewitt-Taylor, 1999). Thus, three kinds of expertise are required: a knowledge of the differences in anatomy, physiology and psychology; the ability to interpret these differences; and the nursing skills and interventions based on these differences need to be mastered (Paladichuk, 1998).

\section{Aims of a training programme}

Thus, when developing a training programme for adult nurses caring for children in a general hospital, special attention should be given to the development of the child and providing psychosocial guidance. Knowledge and skills must be acquired with regard to physiology, pharmacology, neurology, surgery and resuscitation. Furthermore, time in practice - in a PICU - is necessary to give support to the theory (Paladichuk, 1998). Additionally, there will always be a need for refresher courses when nurses work with children on an infrequent basis.

\section{Transfer to PICU}

Transfer of a child to a PICU should be undertaken by the ambulance service under the guidance and responsibility of a qualified (assistant) paediatrician (intensive care doctor) or anaesthetist (van der Meulen, 1995).

\section{Basic care standards in AICU}

The basic standards for adequate care in all stages of hospitalisation of a child in an AICU, are listed in Table 3. Protocols for the intensive care nursing of children within an AICU should be developed and would greatly increase the quality of care for these children.

\section{Table 3. Basic standards of care for child in AICU}

- Availability of a paediatrician 24 hours a day

- Appropriate (age-relevant) care of the child and its parents in an AICU, e.g. psychosocial guidance, a child-friendly environment

- Appropriate medical equipment for (small) children

- Appropriate education support, including courses for the nurses of an AICU

- A system of manpower allocation, in which the available expertise is appropriately managed, with, if necessary, adjustment of the staff structure (Consensus Intensive Care Committee, 1995)

- Paediatric advanced life support course for nursing staff in adult intensive care units and emergency and accident departments

\section{CONCLUSION}

In our experience, in the Netherlands, nursing children in an AICU is not possible without a loss of quality of nursing care. Adult intensive care nurses have insufficient theoretical knowledge of, and experience, in nursing children in need of intensive care. Children who are in need of intensive care have a right to the best quality care. The outcome of children in a PICU is much better compared to the outcome of children who are admitted to an adult ICU. Whereas a specialised team is responsible for quality of care in a PICU, an AICU cannot offer this kind of support. However, children are still being admitted to adult intensive care facilities. While this situation continues, the AICU must meet as many of the above standards as possible to improve nursing care and to help optimise the eventual outcome, until the child can be transferred to a PICU.

\section{REFERENCES}

Consensus Intensive Care Committee. (1995). Opvang van ernstig zieke kinderen in het Westeinde Ziekenhuis. (Internal communication.) The Hague, The Netherlands. October. (Admission of critically ill children in the Westeinde Hospital.) [Dutch]

Duval ELIM. (1997). Cardiopulmonale resuscitatie bij kinderen. Deel 1: Kinderen zijn geen kleine volwassenen. Kritiek; 15: 3-7. (Cardiopulmonary resuscitation in children. Part 1: Children are no small adults.)

Gemke RJBJ. (1996). Aanwinst of schijnwinst. In: Op weg naar 2000, 10 jaar intensive care kinderen, Syllabus AZVU. (Acquisition or appearance. In: On the way to 2000. 10 years of paediatric intensive care. Symposium proceedings. VU medical centre.) [Dutch]

Gemke RJBJ. (1997). Centralisation of paediatric intensive care to improve outcome. Lancet; 349: 1187-1188.

Gemke RJBJ, Bonsel GJ, Vught van AJ. (1995). Long term survival and state of health after paediatric intensive care. Archives of Disease in Childhood; 73: 196-201.

Hewitt-Taylor J. (1999) Children in intensive care: physiological considerations. Nursing in Critical Care; 4: 40-45.

Köhler W. (1998). We zeggen niet graag nee. (We don’t say no easily.) [Interview with RJBK Gemke.] NRC Handelsblad; 31 October. [Dutch]

Latour JM. (1998a). Cardiopulmonale resuscitatie bij kinderen. Deel 4: Interventies bij ongevallen. Kritiek; 16: 3-7. (Cardiopulmonary resuscitation in children. Part 4: Interventions at trauma.)

Latour JM. (1998b). Cardiopulmonale resuscitatie bij kinderen. Deel 5: Professionele aandachtsgebieden. Kritiek; 16: 3-7. (Cardiopulmonary resuscitation in children. Part 5: Professional issues.)

Latour J. (2000). Cardiopulmonary resuscitation in infants and children. In: Williams C, Asquith J, (eds.), Paedriatric Intensiev Care Nursing. London: Churchill Livingstone.

Macnab A, Macrae D, Henning R. (1999). Care of the critically ill child. London: Churchill Livingstone.

Paladichuk A. (1998). Children in the adult ICU, preparation and practice. [Interview with MF Hazinski.] Critical Care Nurse; 18: 82-87.

Pearson W, Shann F, Barry P, Thomas D, Powell C, Field D. (1997) Should paediatric intensive care be centralised? Trent versus Victoria. The Lancet; 349: 1213-1217.

Pollack MM, Alexander SR, Clarke $\mathrm{N}$ et al. (1991). Improved outcome from tertiary center pediatric intensive care: a statewide comparison of tertiary and non-tertiary care facilities. Critical Care Medicine; 19: 150-159.

Sanders-Woutstra JAR. (1988). Het kind, een inleiding tot het thema. Tijdschrift voor Ziekenverpleging; 43: 69-73. (The child, introduction to the theme.) [Dutch]

Simpson D, Ridley P. (1982). Pediatric come scale. The Lancet: ii: 450.

Teasdale G, Jennet B. (1974). Assessment of coma and impaired consciousness: a practical scale. The Lancet; ii: 81-84.

Turner NM. (1997). Cardiopulmonale resuscitatie bij kinderen. Deel 2: Basic life support. Kritiek; 15: 3-9. (Cardiopulmonary resuscitation in children. Part 2: Basic life support.)

Turner NM. (1998). Cardiopulmonale resuscitatie bij kinderen. Deel 3: Advanced life support. Kritiek; 15: 3-7. (Cardiopulmonary resuscitation in children. Part 3: Advanced life support.)

Van der Brink GTWJ, Rooijen van APN, Simons R, Uffink THJA. (1995). Leerboek Intensive Care Verpleegkunde Kinderen. Utrecht: Lemma. (Textbook Paediatric Intensive Care Nursing.) [Dutch]

Van der Meulen M, Klop E. (1995). Westeinde Hospital, with regard to refresher courses of intensive care nurses in nursing of children in the general intensive care. (Internal communication.) The Hague: Westeinde Hospital.

Williams C. (2000). Assessment of the critically ill child. In: Williams C, Asquith J, (eds.), Paedriatric Intensiev Care Nursing. London: Churchill Livingstone. 